https://doi.org/10.35339/msz.2019.82.01.10

УДК 613.861:616.895:613.816

І.К. Сосін, К.Д. Гапонов, О.Ю. Гончарова

Харківська медична академія післядипломної освіти

\title{
ПРОГНОЗУВАННЯ ТЯЖКОСТІ РОЗЛАДІВ УНАСЛІДОК УЖИВАННЯ АЛКОГОЛЮ У ХВОРИХ ЗАЛЕЖНО ВІД РІВНЯ ПСИХОСОЦІАЛЬНОГО СТРЕСУ I СТАНУ ГЕПАТОБІЛІАРНОÏ СИСТЕМИ У СВІТЛІ КОНЦЕПЦІЇ IНТЕГРОВАНОЇ ДІАГНОСТИКИ Й ТЕРАПІЇ НАРКОПАТОЛОГІЇ
}

\begin{abstract}
Розробляли спосіб визначення і прогнозування тяжкості розладів, що виникають унаслідок уживання алкоголю, у хворих залежно від рівня психосоціального стресу і стану гепатобіліарної системи у світлі концепції інтегрованої діагностики й терапії наркопатології для використання його лікарями первинної ланки медико-санітарної допомоги. При розробці моделі виділено три основні групи факторів, які, за отриманими даними, мали вплив на формування тяжкості розладів унаслідок уживання алкоголю: вираженість адиктивної симптоматики (за AUDIT), рівень випробовуваного пацієнтами стресового навантаження (за тестом Л. Рідера) та стан гепатобіліарної системи (за коефіцієнтом де Рітіса). Створено модель, яка математично описує співвідношення різних факторів у формуванні тяжкості розладів, що розвиваються внаслідок уживання алкоголю, $\mathrm{i}$ дає можливість кількісно оцінити ймовірнісний стан у конкретного хворого на розлади внаслідок уживання алкоголю. Показано, що запропонована модель характеризується високою детермінантністю і придатна для застосування у практиці охорони здоров'я для прогнозування тяжкості розладів унаслідок уживання алкоголю у хворих на алкогольну залежність.

Ключові слова: алкогольна залежність, тяжкість розладів унаслідок уживання алкоголю, психосоціальний стрес, коефіиієнт де Рітіса, нелінійна багатовимірна модель, моделювання і прогнозування.
\end{abstract}

\section{Вступ}

За формулюванням ВООЗ, інтегрована допомога $€$ концепцією, яка поєднує визначення, надання, управління та організацію послуг, пов'язаних із діагностикою, лікуванням, доглядом, реабілітацією та покращанням здоров'я [1]. ВОО3 узагалі ставить в один ряд поняття «інтегрована допомога» та «допомога, орієнтована на пацієнта» [2].

Така позиція знайшла відображення і в Україні. Ключовим завданням сучасної сис- теми охорони громадського здоров'я, особливо в контексті iii реформування, $\epsilon$ надання якісних медичних послуг шляхом ефективної організації роботи служб залежно від потреб пацієнта, що передбачає інтеграцію рівнів допомоги як ефективний спосіб уникнення зайвого дублювання та покращання якості надання послуг [1].

Незважаючи на те що тісна інтеграція має значні переваги для пацієнтів у більшості систем охорони здоров'я, належне надання ме-

(С І.К. Сосін, К.Д. Гапонов, О.Ю. Гончарова, 2019 
дичних послуг є складним завданням, насамперед через їхню значну фрагментарність. Неналагоджений зв' язок між лікарями загальної практики і вузькоспеціалізованими фахівцями може, наприклад, перешкодити ефективному контролю над хронічними захворюваннями, деякі компоненти допомоги можуть дублюватися, а інші - бути неперсоналізованими та, як наслідок, упущеними. Усі ці фактори тягнуть за собою значні фінансові, ресурсні та організаційні витрати, мінімізація яких також $\epsilon$ одним із завдань інтегрованої допомоги як підходу [2].

Зазначені проблеми характерні і для вітчизняної системи надання наркологічної допомоги, бо у випадку наркопатології дуже важливими є рання діагностика й визначення прогнозу захворювання $[3,4]$. І хоча остаточне встановлення діагнозу психічних і поведінкових розладів унаслідок уживання будь-яких психоактивних речовин належить до компетенції виключно лікаря-нарколога, у більшості випадків пацієнти з проблемами залежної поведінки не прагнуть потрапити в поле зору наркологічної служби, уважаючи, що в будьякий час можуть самостійно відмовитись від уживання / зловживання насамперед алкоголю як найтрадиційнішої для нашого суспільства психоактивної речовини [4]. Попередніми дослідженнями, проведеними на кафедрі наркології Харківської медичної академії післядипломної освіти (завідувач кафедри професор I.К. Сосін) [5], доведено, що «....завдяки сформованим психологічним негативам побутової свідомості і сформованому негативному ставленню до хворих на розлади, пов'язані зі вживанням алкоголю, пацієнти часто приховують наявні в них наркологічні проблеми, ухиляються від первинного звернення до нарколога, а потрапляють на прийом до лікарів первинної ланки медико-санітарної допомоги. При цьому симптоми залежності маскуються соматичними, неврологічними і вегетативними порушеннями, а наркологічна патологія залишається невиявленою».

Ще однією тенденцією сучасної вітчизняної наркології є значно більший (друге місце в світі), ніж у більшості розвинених країн Європи, показник кількості років, утрачених через непрацездатність або передчасні смерті через уживання алкоголю, а також кількості років, які українці живуть 3 алкоголізмом [6].
На думку фахівців, однією із ключових причин, що зумовлює таке становище, $є$ гібридна війна, яка ведеться проти нашої країни з 2014 року. Унаслідок цієї війни суттєво підвищений тягар патологічного стресового навантаження на населення країни [7-9] та збільшений рівень уживання алкоголю, що виникає як несприятливий механізм компенсації нервовопсихічного напруження [10-14].

Хронічна алкогольна інтоксикація неминуче призводить до виникнення структурних $\mathrm{i}$ функціональних змін у різних органах і системах організму, проте основною мішенню токсичної дії етанолу у спектрі соматичних патогномонічних ускладнень алкогольної залежності (А3) є печінка [5]. Вагомим маркером наявності даного захворювання вважають біохімічні показники, що відображають стан внутрішніх органів [15]. Однак, на думку Т.М. Макаренко й О.М. Радченко (2017), «більшість біохімічних показників крові має широкі межі фізіологічних коливань, що зменшує їхнє діагностичне значення для практики, тому більш інформативним як з теоретичної точки зору, так і з клінічної емпіричної є визначення певних співвідношень між біохімічними показниками, які часто є більш інформативними та характеризують конкретні ланки метаболізму та патогенетичних процесів» [16].

Серед загальновизнаних у клінічній практиці співвідношень показників велику увагу привертають співвідношення активності амінотрансфераз крові, що мають діагностичне значення завдяки органо- та органелоспецифічості ензимів [17]. Найвідомішим із них $\epsilon$ коефіцієнт де Рітіса, який відображає співвідношення активності аспартатамінотрансферази (АСТ) і аланінамінотрансферази (АЛТ) крові (АСТ/АЛТ). Обидва ферменти $є$ внутрішньоклітинними, і в сироватці крові здорових людей їхня активність $є$ незначною (АСТ: 0,10-0,45 ммоль/год•л, або 8-40 МО; АЛТ: 0,10-0,68 ммоль/год•л, або 5-30 МО). Відповідно, коефіцієнт де Рітіса становить у

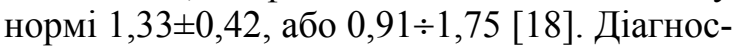
тичне значення має зменшення коефіцієнта де Рітіса менш ніж 1,0 та збільшення понад 2,0 [19, 20]: коефіцієнт менше 1 свідчить про ураження печінки, коефіцієнт ближче до 2 та більше - про ураження серцевого м'яза $[15,21]$.

Таким чином, ураховуючи сучасні тренди діагностики й перебігу АЗ і спираючись на 
результати попередніх досліджень кафедри наркології ХМАПО [3-5], нами розроблено спосіб визначення і прогнозування тяжкості розладів унаслідок уживання алкоголю у хворих залежно від рівня психосоціального стресу і стану гепатобіліарної системи (на основі коефіцієнта де Рітіса) у світлі концепції інтегрованої діагностики й терапії наркопатології для використання його лікарями первинної ланки медико-санітарної допомоги, що й стало метою даної роботи.

\section{Контингент, матеріал і методи}

На базі КНП ХОР «Обласний наркологічний диспансер» протягом 2014-2018 років за умови інформованої згоди з дотриманням принципів біоетики і деонтології обстежено 312 чоловіків, хворих на АЗ: 107 комбатантів, які мали досвід участі в бойових діях на Сході України під час проведення Антитерористичної операції й Операції об'єднаних сил; 89 вимушено переміщених осіб із тимчасово окупованих районів Донецької та Луганської областей та 116 осіб - мешканців м. Харкова і Харківської області, які не були комбатантами або вимушено переміщеними особами.

У дослідженні використовували клінічний, клініко-психопатологічний, психодіагностичний та клініко-лабораторний методи. Алкогольну залежність діагностували за допомогою клініко-психопатологічного методу з використанням діагностичних критеріїв MКХ-10 та психодіагностичного дослідження за допомогою Alcohol Use Disorders Identification Test (AUDIT) для виявлення розладів, пов' язаних зі зловживанням алкоголю, та визначення ступеня небезпечності його вживання [22]. Тяжкість психосоціального стресу вимірювали за однойменною шкалою Л. Рідера [23]. Крім того, установлювали клініко-лабораторні показники, для чого в плазмі крові визначали активність АСТ та АЛТ за Райтманом-Френкелем та розраховували коефіцієнт де Рітіса [19-21].

У тесті AUDIT були запропоновані такі запитання:

1. Як часто Ви вживаєте напої, що містять алкоголь?

2. У якій кількості Ви звичайно вживаєте алкогольні напої, коли випиваєте (за одну добу)?

3. Як часто Ви випиваєте 6 СДА і більше (за одну добу)?

4. Як часто за останній рік Ви виявляли, що, почавши пити алкогольні напої, не може- те зупинитися (випиваєте більше, ніж планували, або п'єте довше, ніж планували)?

5. Як часто за останній рік через надмірне вживання алкоголю Ви не змогли зробити те, що робите звичайно (зневажали навчанням, роботою, домашніми справами або іншими заняттями)?

6. Як часто за останній рік Вам необхідно було похмелитися ранком, щоб отямитися після того, як Ви багато випили напередодні?

7. Як часто за останній рік Ви випробовували почуття провини або каяття совісті після випивки?

8. Як часто за останній рік Ви не могли згадати, що було напередодні ввечері, тому що були п'яні?

9. Чи не стало надмірне вживання Вами алкогольних напоїв причиною отриманих Вами або кимось іншим травм?

10. Хто-небудь із родичів, друг, лікар або інший медичний працівник виражали заклопотаність із приводу Вашого пияцтва або пропонували Вам зменшити кількість уживаного алкоголю?

Статистико-математичний аналіз полягав у формуванні описової статистики та аналізі розбіжностей із використанням непараметричних методів: точного критерію Фішера та критерію $\chi^{2}$ Пірсона.

\section{Результати та їх обговорення}

На початку дослідження в кожній з категорій обстежених було виділено по три групи зі слабкою, помірною та тяжкою вираженістю психосоціального стресу. Віднесення респондента до групи 3 низькою, помірною та тяжкою вираженістю психосоціального стресу проводили на підставі аналізу результатів обстеження за шкалою психосоціального стресу Л. Рідера [23]. У разі, якщо показник за цією шкалою склановив до 0,99 бала, обстежуваного відносили до групи з низьким рівнем стресу; у разі, якщо показник перебував у межах 1,00-1,99 бала, обстежуваного відносили до групи з помірним рівнем стресу; у разі, якщо показник перевищував 1,99 бала, - до групи 3 тяжким рівнем стресу.

Серед комбатантів було 2 особи $(1,9 \%)$ iз низьким рівнем стресу (група К1), 29 осіб $(27,1 \%)$-із помірним (група К2) та 76 (71,0\%) iз високим (група К3). Серед переселенців 9 осіб (10,1 \%) мали низький рівень стресового реагування (група П1), 22 особи $(24,7 \%)-$ 
помірний (група П2) та 58 осіб (65,2 \%) - високий його рівень (група П3). У місцевих мешканців у 24 випадках $(20,7 \%)$ реєстрували низький рівень стресу (група М1), у 33 (28,4 \%) помірний (група М2) та у 59 випадках $(50,9 \%)-$ високий його рівень (група М3).

Таким чином, у дослідженні аналізували дані як за групами респондентів (107 комбатантів, 89 переселенців та 116 місцевих мешканців), так і за групами хворих із різним психосоціальним стресом: 35 обстежених із легким рівнем стресового навантаження [середній показник по групі становив $(0,62 \pm 0,21)$ бала]; 84 - із помірним [середній показник - $(1,39 \pm$ $0,30)$ бала] та 193 - із високим [середній показник - $(2,47 \pm 0,38)$ бала], розбіжності при порівнянні середньої вираженості психосоціального стресу в даних групах були статистично значущими $(\mathrm{p}<0,01)$.

Середні показники вираженості психосоціального стресу в осіб різних соціальних груп становили: у комбатантів - $(2,24 \pm 0,63)$ бала; у переселенців - $(2,03 \pm 0,72)$ бала; у місцевих мешканців - $(1,68 \pm 0,78)$ бала, розбіжності статистично значущі при порівнянні груп комбатантів і місцевих мешканців та переселенців і місцевих мешканців $(\mathrm{p}<0,01)$.

Вираженість клінічних проявів А3 (за AUDIT) у комбатантів становила $(30,43 \pm 7,31)$ бала, у переселенців - $(28,60 \pm 7,78)$ бала, у місцевих мешканців - $(25,43 \pm 8,19)$ бала, розбіжності статистично значущі при порівнянні комбатантів і місцевих мешканців $(\mathrm{p}<0,01)$, переселенців і місцевих мешканців $(\mathrm{p}<0,01)$.

У обстежених із легким стресом середній показник за AUDIT виявився $(15,17 \pm 2,32)$ бала, у обстежених із помірним реагуванням на стрес - $(21,53 \pm 1,99)$ бала, у осіб із тяжким стресом - $(31,51 \pm 6,35)$ бала, розбіжності статистично значущі при порівнянні всіх груп між собою $(\mathrm{p}<0,01)$.

Таким чином, у обстежених із низьким рівнем психосоціального стресу показники за AUDIT становили: у групі К1 - $(16,50 \pm 0,71)$ бала, у П1 - $(15,44 \pm 1,67)$ бала, у M1 - $(14,96 \pm$ $2,60)$ бала; розбіжності між групами статистично незначущі ( $p>0,05)$. У групі з помірним стресом показники за AUDIT дорівнювали: у К2 - $(21,62 \pm 2,14)$ бала, у П2 - $(21,41 \pm 1,82)$ бала, у М2 - $(20,09 \pm 1,21)$ бала; розбіжності значущі при порівнянні груп К2 і М2 та груп П2 та М2 (p<0,05). У групі з вираженим психо- соціальним стресом показники за AUDIT становили: у групі К3 - $(34,16 \pm 4,95)$ бала, у П3 $(33,36 \pm 4,64)$ бала, у M3 - $(32,68 \pm 3,83)$ бала, розбіжності значущі при порівнянні груп К3 та M3 $(\mathrm{p}<0,05)$. При порівнянні показників за AUDIT у групах K1, К2 та К3; П1, П2 та П3; M1, М2 та М3 виявлено значущість розбіжностей: у групі легкого стресу - $<<0,05$, у групах помірного та тяжкого - $<<0,01$ [24].

Окрім розгляду результуючого показника за AUDIT, що визначає тяжкість вираженості розладів унаслідок уживання алкоголю, аналізу піддавали інформацію за окремими питаннями й концептуальними розділами AUDIT: питання 1-3 визначають стиль уживання алкоголю, питання 4-6- ознаки АЗ, питання 7-10 шкідливість наслідків уживання алкоголю [25].

Проаналізувавши тяжкість розладів унаслідок уживання алкоголю за окремими їх ознаками в комбатантів (табл. 1), переселенців (табл. 2) та місцевих мешканців (табл. 3), ми виявили загальну тенденцію наростання тяжкості розладів зі зростанням психосоціального стресового навантаження.

Так, у комбатантів (табл. 1) серед показників, що характеризують стиль уживання (перший домен AUDIT), його частота й типові кількості значуще зростали в динаміці в осіб у міру збільшення рівня психосоціального стресу (значення більше 3 балів за частотою вживання: 0 \% К 1 - 41,4 \% К2 - 81,6 \% К3 відповідно; за кількістю вживання: 0 \% К1 - 6,9\% К2 - 81,6 \% К3 відповідно). Треба зазначити, що надмірне вживання було зафіксовано в усіх обстежених незалежно від рівня випробовуваного стресового навантаження. За вираженістю ознак А3 (другий домен AUDIT) відмічені значущі зміни в бік ускладнення симптоматики щодо зростання пріоритету вживання алкоголю і вживання зранку (значення більше 1 бала: $0 \%$ К 1 - 37,9 \% К2 - 96, 1 \% К3 відповідно; 50,0 \% К1 - 62,1 \% К2 - 100,0 \% К3 відповідно). Зниження контролю над уживанням алкоголю було притаманне всім обстеженим незалежно від рівня стресу. За наявністю i вираженістю шкідливих наслідків уживання алкоголю (третій домен AUDIT) також встановлений негативний дрейф показників у бік ускладнення зі зростанням рівня психосоціального стресу: почуття провини через уживання алкоголю (0 \% К $1-37,9 \%$ К2 - 97,4 \% К3 відповідно), наявність провалів у пам'яті че- 
Таблиия 1. Результати оиінювання тяжкості розладів, пов'язаних із уживанням алкоголю, за допомогою AUDIT у комбатантів залежно від тяжкості психосоиіального стресу

\begin{tabular}{|c|c|c|c|c|c|c|c|c|c|c|}
\hline \multirow{3}{*}{$\begin{array}{l}\text { Питання } \\
\text { AUDIT }\end{array}$} & \multirow{3}{*}{$\begin{array}{c}\text { Діапазон } \\
\text { оцінок, } \\
\text { балів }\end{array}$} & \multicolumn{6}{|c|}{ Рівень психосоціального стресу } & \multirow{3}{*}{$p_{1-2}$} & \multirow{3}{*}{$p_{1-3}$} & \multirow{3}{*}{$\mathrm{p}_{2-3}$} \\
\hline & & \multicolumn{2}{|c|}{ легкий $(\mathrm{n}=2)$} & \multicolumn{2}{|c|}{ помірний (n=29) } & \multicolumn{2}{|c|}{ тяжкий $(\mathrm{n}=76)$} & & & \\
\hline & & абс & $\%$ & абс. & $\%$ & абс. & $\%$ & & & \\
\hline & $0-3$ & 2 & 100,0 & 17 & 58,6 & 14 & 18,4 & \multirow{2}{*}{$>0,05$} & \multirow{2}{*}{$<0,05$} & \multirow{2}{*}{$<0,01$} \\
\hline & Понад 3 & 0 & 0,0 & 12 & 41,4 & 62 & 81,6 & & & \\
\hline \multirow[b]{2}{*}{2} & & 2 & 100,0 & 27 & 93,1 & 14 & 18,4 & \multirow{2}{*}{$>0,05$} & \multirow{2}{*}{$<0,05$} & \multirow{2}{*}{$<0,01$} \\
\hline & нағ & ( & 0,0 & 2 & 6,9 & 62 & 81,6 & & & \\
\hline \multirow{2}{*}{3} & & $\mathrm{c}$ & 0,0 & 0 & 0,0 & 0 & 0,0 & \multirow{2}{*}{$>0,05$} & \multirow{2}{*}{$>0,05$} & \multirow{2}{*}{$>0,05$} \\
\hline & Г & 2 & 100,0 & 29 & 100,0 & 76 & 100,0 & & & \\
\hline & & 0 & 0,0 & 5 & 17,2 & 0 & 0,0 & \multirow{2}{*}{$>0,05$} & \multirow{2}{*}{$>0,05$} & \multirow{2}{*}{$<0,01$} \\
\hline & П & 2 & 100,0 & 24 & 82 , & 76 & 100,0 & & & \\
\hline & 0 & 2 & 100,0 & $1 \varepsilon$ & 62 , & 3 & 3,9 & \multirow{2}{*}{$>0,05$} & \multirow{2}{*}{$<0,01$} & \multirow[b]{2}{*}{$<0,01$} \\
\hline & 1 & c & 0,0 & 11 & 37, & 73 & 96,1 & & & \\
\hline \multirow[t]{2}{*}{6} & 0 & 1 & 50,0 & 11 & 37,9 & 0 & 0,0 & \multirow{2}{*}{$>0,05$} & & \\
\hline & Пона & 1 & 50,0 & 18 & 62,1 & 76 & 100,0 & & 0,01 & $0, \mathrm{C}$ \\
\hline 7 & & 2 & 100,0 & 18 & 62,1 & 2 & 2,6 & & > 01 & $<00$ \\
\hline$y$ & Г & 0 & 0,0 & 11 & 37,9 & 74 & 97,4 & $>0,05$ & $<0,01$ & $<0,0$ \\
\hline 0 & & 1 & 50,0 & 1 & 3 & 0 & 0,0 & 005 & & \\
\hline 8 & Пона & 1 & 50,0 & 28 & 96,6 & 76 & 100,0 & 05 & 01 & $b$ \\
\hline 0 & $0-1$ & 2 & 100,0 & 27 & 93,1 & 17 & 22,4 & & $<005$ & $<0$ \\
\hline 9 & $\Pi$ & 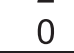 & 0,0 & 10 & 6,9 & 59 & 77,6 & 5 & 15 & 1 \\
\hline & 0 & 2 & 100,0 & 16 & 55,2 & 11 & 14,5 & & & \\
\hline 10 & & 0 & 0,0 & 13 & 44,8 & 65 & 85,5 & $>0,05$ & $<0,01$ & $<0,01$ \\
\hline ий & $0-21$ & 2 & 100,0 & 10 & 34,5 & 0 & 0,0 & & 1001 & 108 \\
\hline показник & Понад 21 & 0 & 0,0 & 19 & 65,5 & 76 & 100,0 & $>0,05$ & $<0,01$ & $<0,01$ \\
\hline
\end{tabular}

Примітка. Рівень статистичної значущості розбіжностей при порівнянні груп: $\mathrm{p}_{1-2}-$ iз легким $\mathrm{i}$ помірним рівнями стресу; $\mathrm{p}_{1-3}-$ iз легким і тяжким рівнями стресу; $\mathrm{p}_{2-3}-$ iз помірним i тяжким рівнями стресу. Тут і в табл. $2-4$.

рез уживання алкоголю $(50,0 \% \mathrm{~K} 1-96,6 \%$ К2 - 100,0 \% К3 відповідно), фізичні травми внаслідок уживання алкоголю (0 \% К $1-6,9 \%$ К2 - 77,6 \% К3 відповідно), стурбованість близького оточення через уживання алкоголю ( 0 \% К1 - 44,8 \% К2 - 85,5 \% К3 відповідно). За загальним результатом показник менше 21 бала був притаманний особам К1 і 34,5 \% К2; у всіх інших - 65,5 \% К2 і 100,0 \% К3 сумарний показник AUDIT становив більш ніж 21 бал, що підтверджувало наявність у них клінічно окресленої АЗ за критеріями МКХ-10.

Надмірну частоту вживання алкоголю встановлено практично в усіх переселенців (у $88,9 \%$ осіб із легким рівнем стресу, у $100,0 \%$ із помірним та у 100,0 \% - із тяжким), інші ж показники, що характеризують стиль уживання (частоту і кількість), зростали зі збільшенням стресового навантаження ( $0 \%$ П1 - 45,5\% П2 86,2 \% П3 відповідно; 0 \% П1 - 13,6 \% П2 79,3 \% ПЗ відповідно), табл. 2. Таку саму тенденцію, окрім зниження контролю над уживанням $(100,0 \% \Pi 1-77,3 \%$ П $-98,3 \%$ П3 відповідно), було встановлено при аналізі ознак А3: зростання пріоритету вживання над іншими справами $(22,2 \%$ П1 - 27,3 \% П2 96,6 \% П3 відповідно) та вживання алкоголю зранку (55,6 \% П1 - 59,1 \% П2 - 98,3 \% П3 відповідно). Шкідливі наслідки вживання алкоголю також збільшувались з ускладненням реагування на стрес: зафіксоване зростання відчуття провини після вживання алкоголю ( $0 \%$ П1 - 27,3\% П2 - 98,3\% П3 відповідно), провалів у пам'яті через уживання алкоголю (22,2 \% П1 - 100,0 \% П2 - 100,0 \% П3 відповідно) та стурбованості оточуючих (0 \% П1 40,9 \% П2 - 89,7 \% П3 відповідно). Випадки побутового травматизму як наслідку вживання алкоголю встановлено в 75,9 \% пацієнтів із тяжким психосоціальним стресом (П3). Динаміка сумарного показника була чітко співставлена з рівнем стресу: менше 21 бала мало місце у $100,0 \%$ осіб із легким рівнем стресу (П1) i у 50,0\% - із помірним (П2), більше 21 бала - у 50,0\% пацієнтів із помірним стресом (П2) і у 100,0 \% - із тяжким його рівнем (П3). 
Таблиия 2. Результати оцінювання тяжккості розладів, пов'язаних із ужсиванням алкоголю, за допомогою AUDIT у переселенців залежно від тяжкості психосоиіального стресу

\begin{tabular}{|c|c|c|c|c|c|c|c|c|c|c|}
\hline \multirow{3}{*}{$\begin{array}{c}\text { Питання } \\
\text { AUDIT }\end{array}$} & \multirow{3}{*}{$\begin{array}{c}\text { Діапазон } \\
\text { оцінок, } \\
\text { балів }\end{array}$} & \multicolumn{6}{|c|}{ Рівень психосоціального стресу } & \multirow{3}{*}{$\mathrm{p}_{1-2}$} & \multirow{3}{*}{$p_{1-3}$} & \multirow{3}{*}{$\mathrm{p}_{2-3}$} \\
\hline & & \multicolumn{2}{|c|}{ легкий $(n=9)$} & \multicolumn{2}{|c|}{ помірний $(\mathrm{n}=22)$} & \multicolumn{2}{|c|}{ ТЯЖкиЙ $(n=58)$} & & & \\
\hline & & абс. & $\%$ & абс. & $\%$ & абс. & $\%$ & & & \\
\hline 1 & $\begin{array}{l}0-3 \\
\text { Понад } 3\end{array}$ & $\begin{array}{l}9 \\
0\end{array}$ & $\begin{array}{r}100,0 \\
0,0\end{array}$ & $\begin{array}{l}12 \\
10\end{array}$ & $\begin{array}{l}54,5 \\
45,5\end{array}$ & $\begin{array}{r}8 \\
50\end{array}$ & $\begin{array}{l}13,8 \\
86,2\end{array}$ & $<0,05$ & $<0,01$ & $<0,01$ \\
\hline 2 & $\begin{array}{l}0-3 \\
\text { Понад } 3\end{array}$ & $\begin{array}{l}9 \\
0\end{array}$ & $\begin{array}{r}100,0 \\
0,0 \\
\end{array}$ & $\begin{array}{r}19 \\
3 \\
\end{array}$ & $\begin{array}{l}86,4 \\
13,6\end{array}$ & $\begin{array}{l}12 \\
46\end{array}$ & $\begin{array}{l}20,7 \\
79,3\end{array}$ & $>0,05$ & $<0,01$ & $<0,01$ \\
\hline 3 & $\begin{array}{l}0-1 \\
\text { Понад } 1\end{array}$ & $\begin{array}{l}1 \\
8\end{array}$ & $\begin{array}{l}11,1 \\
88,9\end{array}$ & $\begin{array}{r}0 \\
22\end{array}$ & $\begin{array}{r}0,0 \\
100,0\end{array}$ & $\begin{array}{r}0 \\
58\end{array}$ & $\begin{array}{r}0,0 \\
100,0\end{array}$ & 0,05 & $<0,05 \mid$ & $>0,05$ \\
\hline 4 & $\begin{array}{l}0-1 \\
\text { Понад } 1\end{array}$ & $\begin{array}{l}0 \\
9\end{array}$ & $\begin{array}{r}0,0 \\
100,0 \\
\end{array}$ & $\begin{array}{r}5 \\
17 \\
\end{array}$ & $\begin{array}{l}22,7 \\
77,3\end{array}$ & $\begin{array}{r}1 \\
57 \\
\end{array}$ & $\begin{array}{r}1,7 \\
98,3 \\
\end{array}$ & $>0,05$ & $>0,05$ & $<0,01$ \\
\hline 5 & $\begin{array}{l}0-1 \\
\text { Понад } 1\end{array}$ & $\begin{array}{l}7 \\
2\end{array}$ & $\begin{array}{l}77,8 \\
22,2\end{array}$ & $\begin{array}{r}16 \\
6\end{array}$ & $\begin{array}{l}72,7 \\
27,3\end{array}$ & $\begin{array}{r}2 \\
56\end{array}$ & $\begin{array}{r}3,4 \\
96,6\end{array}$ & $>0,05$ & $<0,01$ & $<0,01$ \\
\hline 6 & $\begin{array}{l}0-1 \\
\text { Понад } 1\end{array}$ & $\begin{array}{l}4 \\
5\end{array}$ & $\begin{array}{l}44,4 \\
55,6\end{array}$ & $\begin{array}{r}99 \\
13\end{array}$ & $\begin{array}{l}40,9 \\
59,1\end{array}$ & $\begin{array}{r}1 \\
57\end{array}$ & $\begin{array}{r}1,7 \\
98,3\end{array}$ & $>0,05$ & $<0,01$ & $<0,01$ \\
\hline 7 & $\begin{array}{l}0-1 \\
\text { Понад } 1\end{array}$ & $\begin{array}{l}9 \\
0\end{array}$ & $\begin{array}{r}100,0 \\
0,0\end{array}$ & $\begin{array}{c}16 \\
6\end{array}$ & $\begin{array}{l}72,7 \\
27,3\end{array}$ & $\begin{array}{r}1 \\
57\end{array}$ & $\begin{array}{r}1,7 \\
98,3\end{array}$ & $>0,05$ & $<0,01$ & $<0,01$ \\
\hline 8 & $\begin{array}{l}0-1 \\
\text { Понад 1 }\end{array}$ & $\begin{array}{l}7 \\
2\end{array}$ & $\begin{array}{l}77,8 \\
22,2\end{array}$ & $\begin{array}{r}0 \\
22\end{array}$ & $\begin{array}{r}0,0 \\
100,0\end{array}$ & $\begin{array}{r}0 \\
58 \\
\end{array}$ & $\begin{array}{r}0,0 \\
100,0 \\
\end{array}$ & $<0,01$ & $<0,01$ & $>0,05$ \\
\hline 9 & $\begin{array}{l}0-1 \\
\text { Понад 1 }\end{array}$ & $\begin{array}{l}9 \\
0\end{array}$ & $\begin{array}{r}100,0 \\
0,0\end{array}$ & $\begin{array}{r}22 \\
0\end{array}$ & $\begin{array}{r}100,0 \\
0,0\end{array}$ & $\begin{array}{l}14 \\
44\end{array}$ & $\begin{array}{l}24,1 \\
75,9\end{array}$ & $>0,05$ & $<0,01$ & $<0,01$ \\
\hline 10 & $\begin{array}{l}0-2 \\
\text { Понад } 2\end{array}$ & $\begin{array}{l}9 \\
0\end{array}$ & $\begin{array}{r}100,0 \\
0,0 \\
\end{array}$ & $\begin{array}{r}13 \\
9 \\
\end{array}$ & $\begin{array}{l}59,1 \\
40,9\end{array}$ & $\begin{array}{r}6 \\
52 \\
\end{array}$ & $\begin{array}{l}10,3 \\
89,7\end{array}$ & $<0,05$ & $<0,01$ & $<0,01$ \\
\hline $\begin{array}{c}\text { Сумарний } \\
\text { показник }\end{array}$ & $\begin{array}{l}0-21 \\
\text { Понад } 21\end{array}$ & $\begin{array}{l}9 \\
0\end{array}$ & $\begin{array}{r}100,0 \\
0,0 \\
\end{array}$ & $\begin{array}{l}11 \\
11\end{array}$ & $\begin{array}{l}50,0 \\
50,0\end{array}$ & $\begin{array}{r}0 \\
58\end{array}$ & $\begin{array}{r}0,0 \\
100,0\end{array}$ & $<0,01$ & $<0,01$ & $<0,01$ \\
\hline
\end{tabular}

Таблиия 3. Результати оичінювання тяжкості розладів,

пов'язаних зі вживанням алкоголю, за допомогою AUDIT у місиевих мешканців залежно від тяжкості психосоціального стресу

\begin{tabular}{|c|c|c|c|c|c|c|c|c|c|c|}
\hline \multirow{3}{*}{$\begin{array}{c}\text { Питання } \\
\text { AUDIT }\end{array}$} & \multirow{3}{*}{$\begin{array}{c}\text { Діапазон } \\
\text { оцінок, } \\
\text { балів }\end{array}$} & \multicolumn{6}{|c|}{ Рівень психосоціального стресу } & \multirow{3}{*}{$p_{1-2}$} & \multirow{3}{*}{$p_{1-3}$} & \multirow{3}{*}{$p_{2-3}$} \\
\hline & & \multirow{2}{*}{\multicolumn{2}{|c|}{\begin{tabular}{c|c} 
легкий $(\mathrm{n}=24)$ \\
абс.
\end{tabular}}} & \multicolumn{2}{|c|}{ помірний $(\mathrm{n}=33)$} & \multicolumn{2}{|c|}{ тяжкий $(n=59)$} & & & \\
\hline & & & & абс. & $\%$ & абс. & $\%$ & & & \\
\hline \multirow[b]{2}{*}{1} & $0-3$ & 23 & 95,8 & 17 & 51,5 & 12 & 20,3 & \multirow{2}{*}{$<0,01$} & \multirow{2}{*}{$<0,01$} & \multirow{2}{*}{$<0,01$} \\
\hline & Понад 3 & 1 & 4,2 & 16 & 48,5 & 47 & 79,7 & & & \\
\hline 2 & $0-3$ & 24 & 100,0 & 31 & 93,9 & 15 & 25,4 & $>0,05$ & $<0,01$ & $<0,01$ \\
\hline \multirow[b]{2}{*}{3} & na & 6 & 25,0 & 0 & 0,0 & 4 & $\frac{74,0}{0,0}$ & \multirow[b]{2}{*}{$<0,01$} & \multirow[b]{2}{*}{$<0,01$} & \multirow[b]{2}{*}{$>0,05$} \\
\hline & Понад 1 & 18 & 75,0 & 33 & 100,0 & 59 & 100,0 & & & \\
\hline \multirow[b]{2}{*}{4} & & 0 & 0,0 & 5 & 2 & 3 & 5,1 & \multirow{2}{*}{$<0,05$} & \multirow{2}{*}{$>0,05$} & \multirow{2}{*}{$>0,05$} \\
\hline & на & 24 & 100,0 & 28 & 8 & 56 & 94,9 & & & \\
\hline & 0 & 23 & 95,8 & 27 & 8 & 4 & 6,8 & \multirow{2}{*}{$>0,05$} & \multirow{2}{*}{$<0,01$} & \multirow{2}{*}{$<0,01$} \\
\hline & на & 1 & 4,2 & $c$ & 1 & 55 & 93,2 & & & \\
\hline & & 10 & 41,7 & 10 & & 2 & 3,4 & \multirow{2}{*}{$>0,05$} & \multirow{2}{*}{$<0,01$} & $<0,0$ \\
\hline & Пона & 14 & 58,3 & 23 & 69 & 57 & 96,6 & & & $<0,0$ \\
\hline 7 & 0 & 23 & 95,8 & 27 & 81 & 4 & 6,8 & & & \\
\hline$r$ & $\Gamma$ & 1 & 42 & 6 & 18 & 55 & 93,2 & 15 & $<0,01$ & $<0$, \\
\hline 8 & 0 & 18 & 75,0 & 1 & 3,0 & 0 & 0,0 & 11 & 1 & $>0$ \\
\hline 8 & 1 & 6 & 25,0 & 32 & 97,0 & 59 & 100,0 & & & \\
\hline & & 24 & 100,0 & 33 & 100,0 & 1 & 23,7 & & & \\
\hline 9 & Понад 1 & 0 & 0,0 & 0 & 0,0 & 45 & 76,3 & & 1 & 0,6 \\
\hline 10 & $0-2$ & 24 & 100,0 & 30 & 90,9 & 8 & 13,6 & $>0.05$ & $<0.01$ & $<0,01$ \\
\hline & Поне & 0 & 0,0 & 3 & 1 & 51 & 86,4 & $>0,05$ & $<0,01$ & \\
\hline арний & $\begin{array}{l}0-21 \\
\text { Понад 21 }\end{array}$ & $\begin{array}{r}24 \\
0\end{array}$ & $\begin{array}{r}100,0 \\
0\end{array}$ & $\begin{array}{r}29 \\
4\end{array}$ & $\begin{array}{l}87,9 \\
121\end{array}$ & $\begin{array}{r}0 \\
59\end{array}$ & $\begin{array}{r}0,0 \\
1000\end{array}$ & $>0,05$ & $<0,01$ & $<0,01$ \\
\hline & Понад 21 & 0 & 0,0 & 4 & & 59 & & & & . \\
\hline
\end{tabular}


Оцінивши тяжкість розладів унаслідок уживання алкоголю в місцевих мешканців, ми підтвердили виявлену закономірність щодо іiі збільшення в міру зростання реагування на стресове навантаження (табл. 3). У обстежених цього контингенту, так само, як і у хворих інших соціальних груп, зустрічались симптоми збільшення частоти $(4,2 \% \mathrm{M} 1-48,5 \%$ М2 - 79,7 \% М3 відповідно) та типової кількості вживання (0 \% M1 - 6,1 \% M2 - 74,6 \% М3 відповідно) зі збільшенням рівня психосоціального стресу на тлі спільної високої частоти надмірного вживання алкоголю $(75,0 \%$ M1 - 100,0 \% M2 - 100,0 \% М3 відповідно). Закономірностями, порівнянними з установленими в пацієнтів інших соціальних груп, виявились тенденції до збільшення вираженості ознак АЗ у вигляді зростання пріоритету вживання $(4,2 \% \mathrm{M} 1$ - 18,2 \% M2 - 93,2 \% M3 відповідно) та ранкового вживання алкоголю (58,3 \% M1 - 69,7 \% M2 - 96,6 \% М3 відповідно) у респондентів у міру ускладнення рівня психосоціального стресу на тлі загального зниження контролю над уживанням алкоголю (100,0 \% M1 - 84,8 \% M2 - 94,9 \% М3 відпо- відно). Такі самі закономірності встановлено й за показником шкідливих наслідків уживання алкоголю: зростання почуття провини після вживання (4,2 \% M1 - 18,2\% M2 - 93,2 \% M3 відповідно), провали в пам'яті (25,0 \% M1 97,0 \% M2 - 100,0 \% М3 відповідно), побутовий травматизм (0\% M1 - $0 \%$ M2 - 76,3\% M3 відповідно), стурбованість близьких (0 \% M1 9,1 \% M2 - 86,4 \% М3 відповідно), вони спостерігались у міру збільшення стресового рівня, випробовуваного пацієнтами. Сумарний показник за AUDIT менше 21 бала мав місце у 100,0 \% M1 і 87,9 \% M2, більше 21 бала - у $12,1 \%$ M2 i $100,0 \%$ M3.

Узагальнивши результати по загальній вибірці хворих, ми підтвердили виявлений тренд щодо патологічного дрейфу тяжкості симптоматики розладів унаслідок уживання алкоголю зі збільшенням рівня психосоціального стресового навантаження (табл. 4). Так, за всіма показниками, що характеризують стиль уживання алкоголю, окрім частоти надмірного вживання алкоголю, яка була зависокою в усіх респондентів $(80,0 \%-100,0 \%-$ 100,0 \% відповідно), спостерігалась тенденція

Таблиия 4. Результати оцінювання тяжкості розладів, пов'язаних

із уживанням алкоголю, за допомогою AUDIT у всіх обстежених залежно від тяжкості випробуваного психосоціального стресу

\begin{tabular}{|c|c|c|c|c|c|c|c|c|c|c|}
\hline \multirow{3}{*}{$\begin{array}{c}\text { Питання } \\
\text { AUDIT }\end{array}$} & \multirow{3}{*}{$\begin{array}{c}\text { Діапазон } \\
\text { оцінок, } \\
\text { балів }\end{array}$} & \multicolumn{6}{|c|}{ Рівень психосоціального стресу } & \multirow{3}{*}{$p_{1-2}$} & \multirow{3}{*}{$p_{1-3}$} & \multirow{3}{*}{$\mathrm{p}_{2-3}$} \\
\hline & & \multicolumn{2}{|c|}{ легкий $(n=35)$} & \multicolumn{2}{|c|}{ помірний $(\mathrm{n}=84)$} & \multicolumn{2}{|c|}{ тяжкий $(\mathrm{n}=193)$} & & & \\
\hline & & абс. & $\%$ & абс. & $\%$ & абс. & $\%$ & & & \\
\hline \multirow{2}{*}{1} & $0-3$ & 34 & 97,1 & 46 & 54,8 & 34 & 17,6 & \multirow{2}{*}{$<0,01$} & \multirow{2}{*}{$<0,01$} & \multirow{2}{*}{$<0,01$} \\
\hline & Понад 3 & 1 & 2,9 & 38 & 45,2 & 159 & 82,4 & & & \\
\hline \multirow[b]{2}{*}{2} & $0-3$ & 35 & 100,0 & 77 & 91,7 & 41 & 21,2 & \multirow{2}{*}{$>0,05$} & \multirow[b]{2}{*}{$<0,01$} & \multirow[b]{2}{*}{$<0,01$} \\
\hline & Понад 3 & 0 & 0,0 & 7 & 8,3 & 152 & 78,8 & & & \\
\hline \multirow[b]{2}{*}{3} & $0-1$ & 7 & 20,0 & 0 & 0,0 & 0 & 0,0 & \multirow[b]{2}{*}{$<0,01$} & \multirow{2}{*}{$<0,01$} & \multirow{2}{*}{$>0,05$} \\
\hline & Понад 1 & 28 & 80,0 & 84 & 100,0 & 193 & 100,0 & & & \\
\hline \multirow[t]{2}{*}{4} & $0-1$ & 0 & 0,0 & 15 & 17,9 & 4 & 2,1 & \multirow{2}{*}{$<0,01$} & \multirow{2}{*}{$>0,05$} & \multirow{2}{*}{$<0,01$} \\
\hline & Понад 1 & 35 & 100,0 & 69 & 82,1 & 189 & 97,9 & & & \\
\hline \multirow{2}{*}{5} & $0-1$ & 32 & 91,4 & 61 & 72,6 & 9 & 4,7 & \multirow{2}{*}{$<0,05$} & \multirow{2}{*}{$<0,01$} & \multirow{2}{*}{$<0,01$} \\
\hline & Понад 1 & 3 & 8,6 & 23 & 27,4 & 184 & 95,3 & & & \\
\hline \multirow{2}{*}{6} & $0-1$ & 15 & 42,9 & 30 & 35,7 & 3 & 1,6 & \multirow[b]{2}{*}{$>0,05$} & & \\
\hline & Понад 1 & 20 & 57,1 & 54 & 64,3 & 190 & 98,4 & & $<0,01$ & $<0,01$ \\
\hline & $0-1$ & 34 & 97,1 & 61 & 72,6 & 7 & 3,6 & & & \\
\hline 7 & Понад 1 & 1 & 2,9 & 23 & 27,4 & 186 & 96,4 & $<0,01$ & $<0,01$ & $<0,01$ \\
\hline 8 & $0-1$ & 26 & 74,3 & 2 & 2,4 & 0 & 0,0 & & & \\
\hline 8 & Понад 1 & 9 & 25,7 & 82 & 97,6 & 193 & 100,0 & $<0,01$ & $<0,01$ & $<0,05$ \\
\hline & $0-1$ & 35 & 100,0 & 82 & 97,6 & 45 & 23,3 & & & \\
\hline 9 & Понад 1 & 0 & 0,0 & 2 & 2,4 & 148 & 76,7 & $>0,05$ & $<0,01$ & $<0,01$ \\
\hline 10 & $0-2$ & 35 & 100,0 & 59 & 70,2 & 25 & 13,0 & $<0$ & $<\cap \Omega 1$ & 1 \\
\hline 10 & Понад 2 & 0 & 0,0 & 25 & 29,8 & 168 & 87,0 & $<0,01$ & $\langle 0,01$ & $<0,01$ \\
\hline Сумарний & $0-21$ & 35 & 100,0 & 50 & 59,5 & 0 & 0,0 & 1 & $<001$ & $<001$ \\
\hline показник & Понад 21 & 0 & 0,0 & 34 & 40,5 & 193 & 100,0 & $<0,01$ & $\langle 0,01$ & $<0,01$ \\
\hline
\end{tabular}


їхнього посилення в осіб із більш тяжким рівнем стресу: за частотою вживання алкоголю (2,9\% - 45,2 \% - 82,4 \% відповідно) та збільшенням типової кількості вживаного алкоголю (0 \% - 8,3\% - 78,8 \% відповідно). Те саме простежувалось і щодо ознак АЗ, окрім зниження контролю над уживанням алкоголю, що було високим у всіх обстежених (100,0 \% $82,1 \%$ - 97,7 \% відповідно). Зростання пріоритету вживання $(8,6 \%-27,4 \%-95,3 \%$ відповідно) та збільшення випадків ранкового вживання (57,1 \% - 64,3 \% - 98,4 \% відповідно) відбувались зі збільшенням рівня стресу. Шкідливі наслідки вживання алкоголю також наростали в міру збільшення випробовування стресового навантаження: зростали почуття провини після прийому алкоголю $(2,9 \%-27,4 \%$ 96,4 \% відповідно), провали в пам'яті внаслідок уживання алкоголю $(25,7 \%-97,6 \%-$ 100,0 \% відповідно), побутовий травматизм на тлі вживання алкоголю $(0 \%-2,4 \%-76,7 \%$ відповідно) та стурбованість оточення щодо наслідків уживання алкоголю (0 \% - 29,8 \% 87,0 \% відповідно). Загальна картина розпо- ділу сумарного показника відповідала раніше описаній тенденції: у 100,0 \% осіб із легким рівнем стресу і у 59,5 \% - із помірним показник був менше 21 бала, у всіх інших (у 40,5 \% осіб із помірним рівнем стресу і у $100,0 \%$ - iз тяжким) - більше 21 бала. Крім того, треба зазначити, що при аналізі узагальнених даних установлено перевагу статистично значущих розбіжностей, що підтверджувало достовірність отриманих результатів.

У дослідженні тяжкості розладів унаслідок уживання алкоголю, здійснене за соціальними групами обстежених (табл. 5), також виявлено відмінності за окремими параметрами AUDIT, що опосередковано підтвердило гіпотезу про вплив стресового навантаження на перебіг АЗ. Так, значущі розбіжності між усіма групами виявлено за такими показниками, як частота вживання алкоголю $(69,2 \%$ комбатантів- 67,4 \% переселенців - 55,2 \% місцевих мешканців), зростання пріоритету вживання алкоголю над іншими справами (78,5 \% комбатантів - 71,9 \% переселенців - 53,4 \% місцевих мешканців), почуття провини (79,4\%

Таблиия 5. Результати оиінювання тяжкості розладів, пов'язаних зі вживанням алкоголю, за допомогою AUDIT у обстежених різних соціальних груп

\begin{tabular}{|c|c|c|c|c|c|c|c|c|c|c|}
\hline \multirow{3}{*}{$\begin{array}{c}\text { Питання } \\
\text { AUDIT }\end{array}$} & \multirow{3}{*}{$\begin{array}{c}\text { Діапазон } \\
\text { оцінок, } \\
\text { балів }\end{array}$} & \multicolumn{6}{|c|}{ Соціальна група } & \multirow{3}{*}{$\mathrm{p}_{1-2}$} & \multirow{3}{*}{$p_{1-3}$} & \multirow{3}{*}{$p_{2-3}$} \\
\hline & & \multicolumn{2}{|c|}{$\begin{array}{c}\text { комбатанти } \\
(\mathrm{n}=107)\end{array}$} & \multicolumn{2}{|c|}{$\begin{array}{c}\text { переселенці } \\
(\mathrm{n}=89)\end{array}$} & \multicolumn{2}{|c|}{$\begin{array}{l}\text { місцеві мешканці } \\
(\mathrm{n}=116)\end{array}$} & & & \\
\hline & & абс. & $\%$ & абс. & $\%$ & aбc. & $\%$ & & & \\
\hline 1 & $\begin{array}{l}0-3 \\
\text { Понал } 3\end{array}$ & $\begin{array}{l}33 \\
74\end{array}$ & $\begin{array}{l}30,8 \\
692\end{array}$ & $\begin{array}{l}29 \\
60\end{array}$ & $\begin{array}{l}32,6 \\
674\end{array}$ & $\begin{array}{l}52 \\
64\end{array}$ & $\begin{array}{l}44,8 \\
552\end{array}$ & $<0,01$ & $<0,01$ & $<0,0$ \\
\hline 2 & $\begin{array}{l}0-3 \\
\text { Понад } 3\end{array}$ & $\begin{array}{l}43 \\
64\end{array}$ & $\begin{array}{l}40,2 \\
59,2\end{array}$ & $\begin{array}{l}40 \\
49\end{array}$ & $\begin{array}{l}44,9 \\
55,1\end{array}$ & $\begin{array}{l}70 \\
46\end{array}$ & $\begin{array}{l}60,3 \\
39,7\end{array}$ & $>0,05$ & $<0,01$ & $<0,0$ \\
\hline 3 & $\begin{array}{l}0 \\
\Pi\end{array}$ & $\begin{array}{r}0 \\
107\end{array}$ & $\begin{array}{r}0,0 \\
100,0\end{array}$ & $\begin{array}{r}1 \\
88\end{array}$ & $\begin{array}{r}1,1 \\
98,9\end{array}$ & $\begin{array}{r}6 \\
110\end{array}$ & $\begin{array}{r}5,2 \\
94,8\end{array}$ & $<0,01$ & $<0,01$ & $>0$ \\
\hline 4 & $\begin{array}{l}0- \\
\Pi\end{array}$ & $\begin{array}{r}5 \\
102\end{array}$ & $\begin{array}{r}4,7 \\
95,3\end{array}$ & $\begin{array}{r}6 \\
83\end{array}$ & $\begin{array}{r}6,7 \\
93,3\end{array}$ & $\begin{array}{r}8 \\
108\end{array}$ & $\begin{array}{r}6,9 \\
93,1\end{array}$ & $<0,01$ & 0,05 & $<0$ \\
\hline 5 & . & $\begin{array}{l}23 \\
84\end{array}$ & $\begin{array}{l}21,5 \\
78,5\end{array}$ & $\begin{array}{l}25 \\
64\end{array}$ & $\begin{array}{l}28,1 \\
71,9\end{array}$ & $\begin{array}{l}54 \\
62\end{array}$ & $\begin{array}{l}46,6 \\
53,4\end{array}$ & $<0,05$ & $<0,01$ & $<0$, \\
\hline 6 & $\begin{array}{l}0-1 \\
\text { Понад } 1\end{array}$ & $\begin{array}{l}12 \\
95\end{array}$ & $\begin{array}{l}11,2 \\
88,8\end{array}$ & $\begin{array}{l}14 \\
75\end{array}$ & $\begin{array}{l}15,7 \\
84,3\end{array}$ & $\begin{array}{l}22 \\
94\end{array}$ & $\begin{array}{l}19,0 \\
81,0\end{array}$ & $>0,05$ & 0,01 & $<$ \\
\hline 7 & $\begin{array}{l}0 \\
\Pi\end{array}$ & $\begin{array}{l}22 \\
85\end{array}$ & $\begin{array}{l}20,6 \\
79,4\end{array}$ & $\begin{array}{l}26 \\
63\end{array}$ & $\begin{array}{l}29,2 \\
70,8\end{array}$ & $\begin{array}{l}54 \\
62\end{array}$ & $\begin{array}{l}46,6 \\
53,4\end{array}$ & $<0,01$ & $<0,01$ & $<0, C$ \\
\hline 8 & & $\begin{array}{r}2 \\
105\end{array}$ & $\begin{array}{r}1,9 \\
98,1\end{array}$ & $\begin{array}{r}7 \\
82\end{array}$ & $\begin{array}{r}7,9 \\
92,1\end{array}$ & $\begin{array}{l}19 \\
97\end{array}$ & $\begin{array}{l}16,4 \\
83,6\end{array}$ & $<0,01$ & $<0,01$ & $<0,0$ \\
\hline 9 & $\begin{array}{l}0-1 \\
\text { Понад } 1\end{array}$ & $\begin{array}{l}46 \\
61\end{array}$ & 43,0 & $\begin{array}{l}45 \\
44\end{array}$ & $\begin{array}{l}50,6 \\
49,4\end{array}$ & $\begin{array}{l}71 \\
45\end{array}$ & $\begin{array}{l}61,2 \\
38,8\end{array}$ & $>0,05$ & $<0,01$ & $<0,0$ \\
\hline 10 & $\begin{array}{l}0-2 \\
\text { Пона }\end{array}$ & $\begin{array}{l}29 \\
78\end{array}$ & $\begin{array}{l}27,1 \\
72,9\end{array}$ & $\begin{array}{l}28 \\
61\end{array}$ & $\begin{array}{l}31,5 \\
68,5\end{array}$ & $\begin{array}{l}62 \\
54\end{array}$ & $\begin{array}{l}53,4 \\
46,6\end{array}$ & $<0,01$ & $<0,01$ & $<0,0$ \\
\hline $\begin{array}{c}\text { Сумарний } \\
\text { показник }\end{array}$ & $\begin{array}{l}0-21 \\
\text { Понад } 21\end{array}$ & $\begin{array}{l}12 \\
95\end{array}$ & $\begin{array}{l}11,2 \\
88,8\end{array}$ & $\begin{array}{l}20 \\
69\end{array}$ & $\begin{array}{l}22,5 \\
77,5\end{array}$ & $\begin{array}{l}53 \\
63\end{array}$ & $\begin{array}{l}45,7 \\
54,3\end{array}$ & $<0,01$ & $<0,01$ & $<0,0$ \\
\hline
\end{tabular}

Примітка. Рівень статистичної значущості розбіжностей при порівнянні груп: $\mathrm{p}_{1-2}-$ комбатантів i переселенців; $\mathrm{p}_{1-3}$ - комбатантів і місцевих мешканців; $\mathrm{p}_{2-3}-$ переселенців і місцевих мешканців. 
комбатантів - 70,8 \% переселенців - 53,4 \% місцевих мешканців) та провали в пам'яті після вживання алкоголю $(98,1 \%$ комбатантів $92,1 \%$ переселенців - 83,6 \% місцевих мешканців), стурбованість оточення щодо вживання пацієнтом алкоголю (72,9\% комбатантів $68,5 \%$ переселенців - 46,6 \% місцевих мешканців), а також за розподілом сумарного показника: менше 21 бала було виявлено в $11,2 \%$ комбатантів, 22,5\% переселенців та 45,7 \% місцевих мешканців; відповідно до цього результат більше 21 бала був характерним для 88,8 \% комбатантів, 77,5\% переселенців та 54,3\% місцевих мешканців.

Проаналізовано значущість розбіжностей показників за субшкалами AUDIT та встановлено (табл. б), що групи комбатантів, виму- шеними переселенцями за субшкалою № 8 $(\mathrm{p}<0,05)$, між вимушеними переселенцями i місцевими мешканцями за субшкалами № 5 , $7,10(\mathrm{p}<0,01)$ та № $2(\mathrm{p}<0,05)$. За сумарним показником виявлено статистично значущі розбіжності при порівнянні груп комбатантів iз вимушеними переселенцями $(\mathrm{p}<0,05)$, комбатантів із місцевими мешканцями $(\mathrm{p}<0,01)$ та вимушених переселенців із місцевими мешканцями $(\mathrm{p}<0,01)$. Як видно з наведених даних, відмінності між комбатантами і переселенцями менш суттєві, ніж при порівнянні комбатантів і переселенців із місцевими мешканцями. Даний факт підтверджує наявні дані щодо значущості фактора участі в бойових діях та вимушеного переселення в генезі А3. Однак, як свідчать дані нашого дослідження,

Таблиия 6. Результати аналізу статистичної значущості розбіжностей у тяжкості розладів, пов'язаних із вживанням алкоголю, за допомогою AUDIT при порівнянні клінічних груп у межах легкого, помірного та тяжкого ступенів тяжкості психосоиіального стресу

\begin{tabular}{|c|c|c|c|c|c|c|c|c|c|c|c|c|}
\hline \multirow{3}{*}{$\begin{array}{c}\text { Питання } \\
\text { AUDIT }\end{array}$} & \multicolumn{9}{|c|}{ Рівень психосоціального стресу } & \multirow{2}{*}{\multicolumn{3}{|c|}{ Усього }} \\
\hline & \multicolumn{3}{|c|}{ легкий } & \multicolumn{3}{|c|}{ помірний } & \multicolumn{3}{|c|}{ тяжкий } & & & \\
\hline & K vs $\Pi$ & K vs M & ח vs M & K vs $\Pi$ & K vs M & $\Pi$ vs M & K vs $\Pi$ & K vs M & $\Pi$ vs M & K vs $\Pi$ & K vs M & П vs M \\
\hline 1 & $>0,05$ & $>0,05$ & $>0,05$ & $>0,05$ & $>0,05$ & $>0,05$ & $>0,05$ & $>0,05$ & $>0,05$ & $>0,05$ & $<0,05$ & $>0,05$ \\
\hline 2 & $>0,05$ & $>0,05$ & $>0,05$ & $>0,05$ & $>0,05$ & $>0,05$ & $>0,05$ & $>0,05$ & $>0,05$ & $>0,05$ & $<0,01$ & $<0,05$ \\
\hline 3 & $>0,05$ & $>0,05$ & $>0,05$ & $>0,05$ & $>0,05$ & $>0,05$ & $>0,05$ & $>0,05$ & $>0,05$ & $>0,05$ & $<0,05$ & $>0,05$ \\
\hline 4 & $>0,05$ & $>0,05$ & $>0,05$ & $>0,05$ & $>0,05$ & $>0,05$ & $>0,05$ & $<0,05$ & $>0,05$ & $>0,05$ & $>0,05$ & $>0,05$ \\
\hline 5 & $>0,05$ & $>0,05$ & $>0,05$ & $>0,05$ & $>0,05$ & $>0,05$ & $>0,05$ & $>0,05$ & $>0,05$ & $>0,05$ & $<0,01$ & $<0,01$ \\
\hline 6 & $>0,05$ & $>0,05$ & $>0,05$ & $>0,05$ & $>0,05$ & $>0,05$ & $>0,05$ & $>0,05$ & $>0,05$ & $>0,05$ & $>0,05$ & $>0,05$ \\
\hline 7 & $>0,05$ & $>0,05$ & $>0,05$ & $>0,05$ & $>0,05$ & $>0,05$ & $>0,05$ & $>0,05$ & $>0,05$ & $>0,05$ & $<0,01$ & $<0,01$ \\
\hline 8 & $>0,05$ & $>0,05$ & $>0,05$ & $>0,05$ & $>0,05$ & $>0,05$ & $>0,05$ & $>0,05$ & $>0,05$ & $<0,05$ & $<0,01$ & $>0,05$ \\
\hline 9 & $>0,05$ & $>0,05$ & $>0,05$ & $>0,05$ & $>0,05$ & $>0,05$ & $>0,05$ & $>0,05$ & $>0,05$ & $>0,05$ & $<0,01$ & $>0,05$ \\
\hline 10 & $>0,05$ & $>0,05$ & $>0,05$ & $>0,05$ & $<0,01$ & $<0,01$ & $>0,05$ & $>0,05$ & $>0,05$ & $>0,05$ & $<0,01$ & $<0,01$ \\
\hline $\begin{array}{c}\text { Сумарний } \\
\text { показник }\end{array}$ & $>0,05$ & $>0,05$ & $>0,05$ & $>0,05$ & $<0,01$ & $<0,01$ & $>0,05$ & $>0,05$ & $>0,05$ & $<0,05$ & $<0,01$ & $<0,01$ \\
\hline
\end{tabular}

Примітка. К - комбатанти; П - переселенці; М - місцеві мешканці.

шених переселенців та місцевих мешканців значуще не відрізнялися одна від одної за всіма субшкалами, окрім субшкали стурбованості оточуючих алкоголізацією суб'єкта (субшкала № 10), за якою виявлено значущі відмінності між комбатантами й місцевими мешканцями, а також переселенцями і місцевими мешканцями з помірним рівнем психосоціального стресу $(\mathrm{p}<0,01)$. Натомість при порівнянні показників комбатантів, переселенців та місцевих мешканців з усіма рівнями психосоціального стресу виявлено значущі відмінності між комбатантами і місцевими мешканцями за субшкалами тесту № $2,5,7,8,9,10(\mathrm{p}<0,01)$ та № 1 і $3(\mathrm{p}<0,05)$, між комбатантами і виму- за значущістю цей фактор суттєво поступається фактору тяжкості психосоціального стресу, який відіграє вирішальну роль у визначенні тяжкості АЗ.

У аналізі біохімічних показників крові 3 вирахуванням коефіцієнта де Рітіса об'єктивно підтверджено гіпотезу щодо ускладнення симптоматики А3 зі збільшенням рівня психосоціального стресу, випробуваного хворими (табл. 7). Так, між особами з легким, помірним та тяжким рівнями психосоціального стресу мали місце значущі розбіжності $(\mathrm{p}<0,01)$ за коефіцієнтом де Рітіса: від практично нормативних значень $(1,00 \pm 0,26)$ у пацієнтів із легким рівнем стресу до знижених $(0,69 \pm 0,04)-$ 
Таблиця 7. Показники печінкових ферментів у осіб з АЗ залежно від рівня випробовуваного ними стресу

\begin{tabular}{l|c|c|c|c|c|c}
\hline \multirow{2}{*}{\multicolumn{1}{c|}{ Показник }} & \multicolumn{2}{|c|}{ Рівень психосоціального стресу } & \multirow{2}{*}{$\mathrm{p}_{1-2}$} & \multirow{2}{*}{$\mathrm{p}_{1-3}$} & \multirow{2}{*}{$\mathrm{p}_{2-3}$} \\
\cline { 2 - 4 } & легкий & помірний & тяжкий & & & \\
\hline АЛТ, ммоль/год·л & $1,23 \pm 0,69$ & $1,53 \pm 0,77$ & $1,71 \pm 0,86$ & $<0,01$ & $<0,01$ & $>0,05$ \\
АСТ, ммоль/год·л & $1,11 \pm 0,49$ & $1,06 \pm 0,53$ & $0,88 \pm 0,43$ & $>0,05$ & $<0,01$ & $<0,01$ \\
Коефріцієнт де Рітіса & $1,00 \pm 0,26$ & $0,69 \pm 0,04$ & $0,52 \pm 0,08$ & $<0,01$ & $<0,01$ & $<0,01$ \\
\hline
\end{tabular}

Примітка. Рівень статистичної значущості розбіжностей при порівнянні груп: $\mathrm{p}_{1-2}-$ iз легким $\mathrm{i}$ помірним рівнями стресу; $\mathrm{p}_{1-3}$ - із легким і тяжким рівнями стресу; $\mathrm{p}_{2-3}$ - із помірним і тяжким рівнями стресу.

у хворих із помірним та низьких $(0,52 \pm 0,08)-$ у хворих із тяжким рівнем стресового навантаження.

За свідченням Т.М. Макаренко й О.М. Радченко (2017), у людини високий вміст АСТ визначається в тканинах печінки, нервової системи, нирок, скелетних м'язів та міокарда у вигляді двох ізоферментів - мітохондріальної і цитоплазматичної АСТ. Аланінамінотрансфераза також $\epsilon$ в багатьох органах, зокрема в печінці, нирках, скелетних м'язах, міокарді та підшлунковій залозі, у вигляді цитозольного і мітохондріального ізоферментів, проте вміст останнього надзвичайно низький. Активність обох трансфераз у крові суттєво зростає під час руйнування клітин, тобто $\epsilon$ критерієм цитолізу. Зменшення коефіцієнта де Рітіса спостерігається за умов зменшення активності АСТ або збільшення активності АЛТ. Оскільки активність цитоплазматичного ізоферменту АЛТ переважає над активністю цитоплазматичного ізоферменту АСТ, цитоліз клітин із виходом обох цитоплазматичних ізоферментів супроводжується зменшенням коефіцієнта де Рітіса менш ніж 1,0 [26], що спостерігається за умов хвороб печінки [16].

Отримані нами дані було застосовано при розробці способу визначення і прогнозування тяжкості розладів унаслідок уживання алкоголю у хворих залежно від рівня психосоціального стресу і стану гепатобіліарної системи (на основі коефіцієнта де Рітіса) у світлі концепції інтегрованої діагностики й терапії наркопатології для використання його лікарями первинної ланки медико-санітарної допомоги.

На базі регресійної моделі створено математичну модель для прогнозування тяжкості АЗ, придатну для застосування за умов первинного етапу надання медичної допомоги.
При розробці моделі були використані такі групи факторів: адикції, психосоціального стресу та органічного ураження гепатобіліарної системи.

Фактор адикції $\left(\mathrm{X}_{a}\right)$ представлений показником за AUDIT, фактор психосоціального стресу $\left(\mathrm{X}_{b}\right)$ - показником за шкалою психосоціального стресу Л. Рідера, фактор органічного ураження гепатобіліарної системи $\left(\mathrm{X}_{c}\right)$ - коефіцієнтом де Рітіса.

Як змінну - відклик при розрахунку моделі використано показник індексу тяжкості залежності (Addiction Severity Index) [27].

Результати підрахунку кореляційної матриці моделі наведено в табл. 8. Як видно 3 отриманих даних, фактор адикції пов'язаний прямим кореляційним зв'язком із такими факторами: психосоціального стресу $(\mathrm{r}=0,979)$, органічного ураження гепатобіліарної системи $(\mathrm{r}=0,852)$, тяжкості залежності $(\mathrm{r}=0,845)$, a також із квадратами значень фактора адикції $(\mathrm{r}=0,992)$, фактора психосоціального стресу $(\mathrm{r}=0,975)$, фактора органічного ураження гепатобіліарної системи $(\mathrm{r}=0,722)$ та показника тяжкості залежності $(\mathrm{r}=0,814)$. Фактор психосоціального стресу пов'язаний прямим кореляційним зв'язком із такими факторами: органічного ураження гепатобіліарної системи $(\mathrm{r}=0,869)$, тяжкості залежності $(\mathrm{r}=0,810)$, а також із квадратами значень фактора адикції $(\mathrm{r}=0,962)$, фактора психосоціального стресу $(\mathrm{r}=0,979)$, фактора органічного ураження гепатобіліарної системи $(\mathrm{r}=0,755)$ та показника тяжкості залежності $(\mathrm{r}=0,789)$. Фактор органічного ураження гепатобіліарної системи пов'язаний зворотним кореляційним зв'язком із показником тяжкості залежності $(\mathrm{r}=-0,694)$ та квадратами значень фактора адикції $(\mathrm{r}=-0,800)$, фактора психосоціального стресу $(\mathrm{r}=-0,799)$, фактора органічного ураження гепатобіліарної системи $(\mathrm{r}=-0,970)$ та показника тяжкості 
Таблиия 8. Кореляџіийна матриия зв'язків факторів адикиії, психосоиіального стресу, органічного ураження гепатобіліарної системи та тяжкості залежності у хворих на АЗ

\begin{tabular}{|c|c|c|c|c|c|c|c|c|}
\hline \multirow{3}{*}{ Відклик } & \multicolumn{8}{|c|}{ Предиктори } \\
\hline & \multirow{2}{*}{ ПШР } & \multirow{2}{*}{ ПШ AUDIT } & \multirow{2}{*}{ КдР } & \multirow{2}{*}{ IT3 } & \multicolumn{4}{|c|}{ квадрати } \\
\hline & & & & & ПШР & ПШ AUDIT & КдР & IT3 \\
\hline ПШР & 1,000000 & 0,979980 & $-0,869017$ & 0,810156 & 0,978708 & 0,961980 & $-0,755555$ & 0,789456 \\
\hline $\begin{array}{l}\text { ПШ } \\
\text { AUDIT }\end{array}$ & 0,979980 & 1,000000 & $-0,845531$ & 0,834363 & 0,975228 & 0,991740 & $-0,721685$ & 0,814031 \\
\hline КдР & $-0,869017$ & $-0,845531$ & 1,000000 & $-0,693836$ & $-0,799426$ & $-0,800509$ & 0,970086 & $-0,678268$ \\
\hline IT3 & 0,810156 & 0,834363 & $-0,693836$ & 1,000000 & 0,872544 & 0,873631 & $-0,530846$ & 0,999116 \\
\hline Квадрати & & & & & & & & \\
\hline ПШР & 0,978708 & 0,975228 & $-0,799426$ & 0,872544 & 1,000000 & 0,982969 & $-0,656466$ & 0,853576 \\
\hline $\begin{array}{l}\text { ПШ } \\
\text { AUDIT }\end{array}$ & 0,961980 & 0,991740 & $-0,800509$ & 0,873631 & 0,982969 & 1,000000 & $-0,658994$ & 0,854754 \\
\hline КдР & $-0,755555$ & $-0,721685$ & 0,970086 & $-0,530846$ & $-0,656466$ & $-0,658994$ & 1,000000 & $-0,515773$ \\
\hline IT3 & 0,789456 & 0,8 & $-0,678268$ & 0,999116 & 0,853576 & 0,854754 & $-0,515773$ & 1,000000 \\
\hline
\end{tabular}

Примітка. ПШР - показник за шкалою Рідера; ПШ AUDIT - показник за шкалою AUDIT; КдР - коефіцієнт де Рітіса; IT3 - індекс тяжкості залежності.

залежності $(\mathrm{r}=-0,678)$. Тяжкість залежності пов'язана прямим кореляційним зв'язком із квадратами значень фактора адикції $(\mathrm{r}=0,874)$, фактора психосоціального стресу $(\mathrm{r}=0,872)$ та фактора органічного ураження гепатобіліарної системи $(\mathrm{r}=0,531)$. Квадрат значення фактора адикції пов' язаний прямим кореляційним зв'язком із квадратами значення фактора органічного ураження гепатобіліарної системи $(\mathrm{r}=0,659)$ і показника тяжкості залежності $(\mathrm{r}=0,855)$. Квадрат значення фактора психосоціального стресу пов'язаний прямим кореляційним зв'язком із квадратами значення фактора органічного ураження гепатобіліарної системи $(\mathrm{r}=0,656)$ та показника тяжкості залежності $(\mathrm{r}=0,853)$, а квадрат значення фактора органічного ураження гепатобіліарної системи - із квадратом значення показника тяжкості залежності $(\mathrm{r}=0,516)$.

У результаті множинного регресійного аналізу установлено: множинний коефіцієнт коре- ляції - 0,95017370; коефіцієнт детермінації 0,90283006; коефіцієнт детермінації уточнений $-0,90091852$; стандартна похибка оцінки 0,05922958; рівень статистичної значущості (p) - 0,00001. Як видно з отриманих даних, множинний коефіцієнт кореляції та коефіцієнт детермінації в цій моделі набули значень, близьких до 1 (0,950 та 0,903 відповідно).

Узагальнені результати обрахунку нелінійної багатовимірної моделі тяжкості залежності у хворих на АЗ наведено в табл. 9. За даними табл. 9, до моделі включено всі фактори (адикції, психосоціального стресу та органічного ураження гепатобіліарної системи) та їхні квадрати. Вільний член у даній моделі дорівнює 6,10977. Загальний рівень статистичної значущості моделі становить понад 99,99\% $(\mathrm{p}<0,00001)$.

Адекватність побудованої моделі оцінювали за допомогою графічного аналізу ( $p u c y$ нок). Як видно $з$ даних рисунка, співвідно-

Таблиия 9. Основні показники нелінійної багатовимірної регресійної моделі психосоціальної дезадаптачї у хворих на АЗ

\begin{tabular}{l|c|c|r|c|r|c}
\hline \multicolumn{1}{c|}{ Показник } & Beta & Похибка Beta & B & Похибка B & \multicolumn{1}{c|}{$\mathrm{t}$} & $\mathrm{p}$ \\
\hline Вільний член & & & 6,10977 & 0,127393 & 47,9602 & 0,000000 \\
Квадрат ПШ AUDIT & 4,79892 & 0,599410 & 0,00204 & 0,000254 & 8,0061 & 0,000000 \\
ПШ AUDIT & $-4,72265$ & 0,597899 & $-0,11042$ & 0,013979 & $-7,8987$ & 0,000000 \\
КдP & $-1,81256$ & 0,166626 & $-1,80565$ & 0,165991 & $-10,8780$ & 0,000000 \\
Квадрат КдР & 1,18708 & 0,136848 & 0,68920 & 0,079452 & 8,6744 & 0,000000 \\
ПШР & 1,28662 & 0,386336 & 0,32163 & 0,096576 & 3,3303 & 0,000974 \\
Квадрат ПШР & $-1,16793$ & 0,379715 & $-0,07860$ & 0,025553 & $-3,0758$ & 0,002290 \\
\hline
\end{tabular}

Прилітка. ПШР - показник за шкалою Рідера; ПШ AUDIT - показник за шкалою AUDIT; КдР коефіцієнт де Рітіса; IT3 - індекс тяжкості залежності; Beta - стандартизований регресійний коефіцієнт; В - нестандартизований регресійний коефіцієнт; $\mathrm{t}$ - кількість ступенів свободи. 


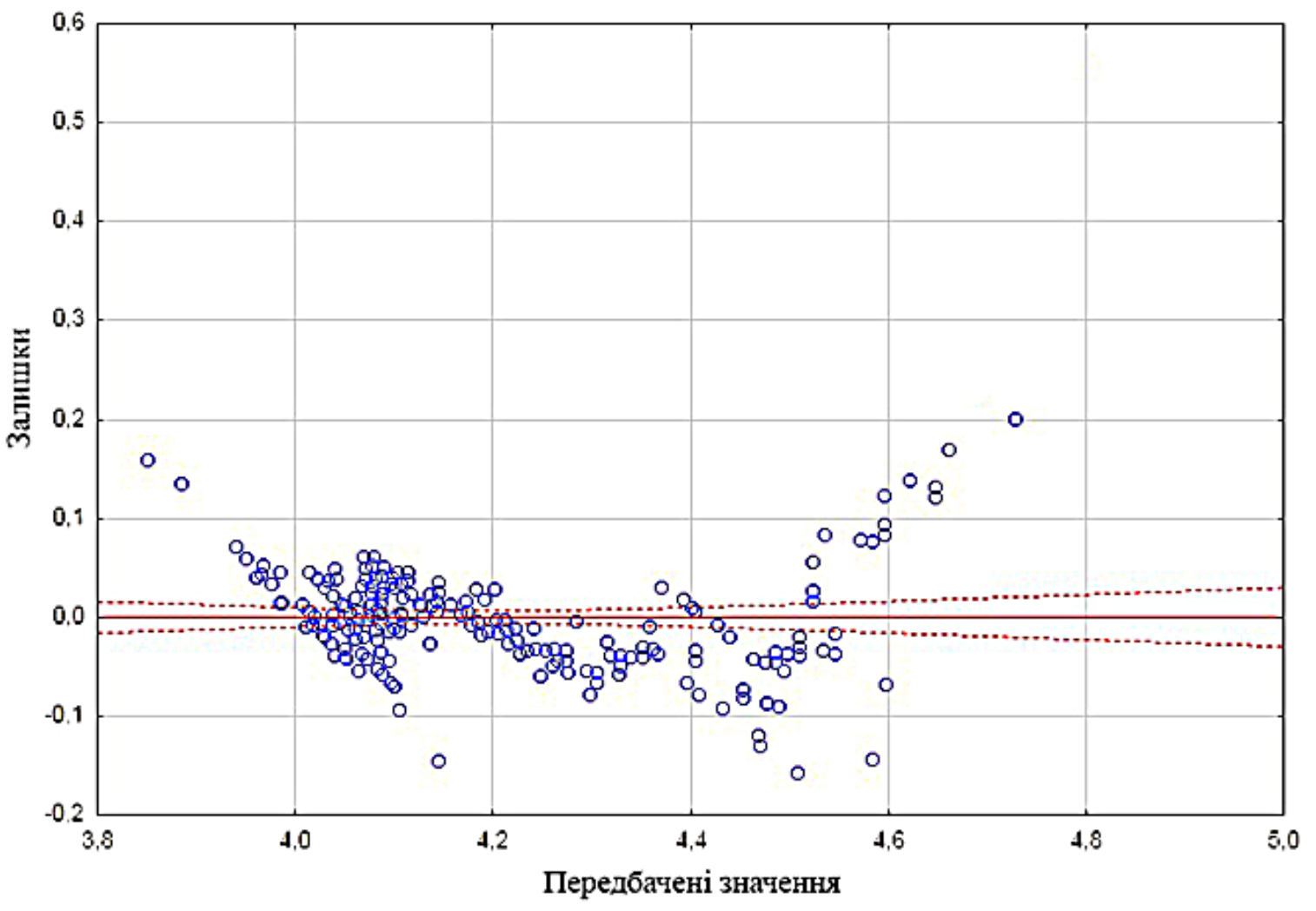

Гістограма розподілу предикторів та залишків

шення передбачених значень і залишків свідчить про адекватність побудованої моделі.

Отже, модель визначення індексу тяжкості залежності у хворих на АЗ набуває такого вигляду:

$$
\begin{gathered}
I T 3=6,10977+\left(0,00204 X_{a}^{2}\right)+\left(-0,11042 X_{a}\right) \\
+\left(-1,80565 X_{c}\right)+\left(0,68920 X_{c}^{2}\right)+ \\
\left(0,32163 X_{b}\right)+\left(-0,07860 X_{b}^{2}\right) .
\end{gathered}
$$

Предиктивну здатність побудованої моделі перевірено на 30 пацієнтах з АЗ, які перебували на лікуванні у КНП ХОР «Обласний наркологічний диспансер».

$\begin{array}{llll}3,00 & 39,00 & 0,40 & 4,53\end{array}$

Загальний рівень вірно передбачених (у межах $\pm 0,10$ бала) значень становив 93,6\%. Як приклад наводимо три спостереження.

1. Пацієнт А.Н., 29 років. Показник за шкалою AUDIT - 22 бали, за шкалою Рідера 1,71 бала, коефіцієнт де Рітіса - 0,67. Розрахунковий показник тяжкості залежності за за- пропонованою моделлю - 4,10 бала. Фактичний показник індексу тяжкості залежності 4,08 бала.

2. Паиієнт В.П., 35 років. Показник за шкалою AUDIT - 35 балів, за шкалою Рідера 2,57 бала, коефіцієнт де Рітіса - 0,61. Розрахунковий показник тяжкості залежності за запропонованою моделлю- 4,23 бала. Фактичний показник індексу тяжкості залежності - 4,20 бала.

3. Паичієн К.К., 53 роки. Показник за шкалою AUDIT - 39 балів, за шкалою Рідера 3,00 бали, коефіцієнт де Рітіса - 0,40. Розрахунковий показник тяжкості залежності за запропонованою моделлю - 4,53 бала. Фактичний показник індексу тяжкості залежності 4,50 бала.

Таким чином, запропонована модель прогнозування тяжкості алкогольної залежності характеризується високою детермінантністю і придатна для застосування як у наркологічній практиці, так і в первинній ланці медико-санітарної допомоги. 


\section{Список літератури}

1. Інтегрована допомога для осіб із психічними та поведінковими розладами внаслідок вживання опіоїдів - пацієнтів замісної підтримувальної терапії : практичний посібник / [Л. Гетьман, Т. Гриценко, І. Іванчук та ін.]. - К. : МБФ «Альянс громадського здоров'я», ТОВ «Агентство «Україна», 2017. $128 \mathrm{c}$.

2. Інтегроване лікування хворих на опіоїдну залежність в умовах центрів первинної медикосанітарної допомоги : навчально-методичний посібник / [С. В. Дворяк, О. Г. Карагодіна, О. С. Морозова та ін.]. - К. : Друкарський двір Олега Федорова, 2016. - 76 с.

3. Наркологія : [національний підручник / за ред. І. К. Сосіна, Ю. Ф. Чуєва]. - Харків : Колегіум, 2014. $-1500 \mathrm{c}$.

4. Рання діагностика алкогольної залежності в практиці сімейного лікаря / І. К. Сосін, І. М. Сквіра, В. М. Міцура [та ін.] // Здобутки клінічної і експериментальної медицини. - 2016. - № 1. - С. 69-72.

5. Інтегрована діагностична ідентифікація алкогольної залежності у загальносоматичній практиці / І. К. Сосін, І. М. Сквіра, Ю. Ф. Чуєв, О. Ю. Гончарова // Східноєвропейський журнал внутрішньої і сімейної медицини. - 2014. - № 1. - С. 95-99.

6. GBD 2016 Alcohol Collaborators. Alcohol use and burden for 195 countries and territories, 19902016: a systematic analysis for the Global Burden of Disease Study 2016 // Lancet Psychiatry. - 2018. Vol. 392, issue 10152. - P. 1015-1035. - pii: S2215-0366(18)30337-7. - DOI : 10.1016/S01406736(18)31310-2.

7. Information and psychological war as a macrosocial stress-development factor of maladaptive states in civilian population: a pathogenetic model and bases of psychocorrection / M. V. Markova, A. R. Markov, N. K. Agisheva, S. A. Martinenko // Psychiatry, psychotherapy and clinical psychology. 2017. - № 4. - P. 534-546.

8. Марута Н. О. Інформаційно-психологічна війна як новий виклик сучасності: стан проблеми та напрямки ії подолання / Н. О. Марута, М. В. Маркова // Український вісник психоневрології. 2015. - Т. 23, вип. 3 (84). - С. 21-28.

9. Маркова М. В. Постстресові дезадаптивні стани на тлі соціальних змін: аналіз проблеми / М. В. Маркова, П. В. Козира // Медична психологія. - 2015. - № 1 (37). - С. 8-13.

10. Becker H. C. Effects of alcohol dependence and withdrawal on stress responsiveness and alcohol consumption / H. C. Becker // Alcohol Research. - 2012. - Vol. 34 (4). - P. 448-458.

11. Moonat S. Stress, epigenetics, and alcoholism / S. Moonat, S. C. Pandey // Alcohol Res. - 2012. Vol. 34 (4). - P. 495-505.

12. Mackey T. K. Responding to the public health consequences of the Ukraine crisis: an opportunity for global health diplomacy / T. K. Mackey, S. A. Strathdee // J. Int. AIDS Soc. - 2015. - Vol. 18. P. 19410.

13. Cadet J. L. Epigenetics of stress, addiction, and resilience: therapeutic implications / J. L. Cadet // Molecular Neurobiology. - 2016. - Vol. 53 (1). - P. 545-560.

14. Palmisano M. Epigenetic mechanisms of alcoholism and stress-related disorders / M. Palmisano, S. C. Pandey // Alcohol. - 2017. - Vol. 60. - P. 7-18.

15. Лінський I. В. Особливості соматичного статусу колишніх військовослужбовців, залежних від алкоголю / І. В. Лінський, А. В. Гайдабрус // Світ медицини та біології. - 2013. - № 4 (42). C. $16-21$.

16. Макаренко Т. М. Співвідношення біохімічних показників крові в медичній практиці: клінікодіагностичне значення / Т. М. Макаренко, О. М. Радченко // Практикуючий лікар. - 2017. - Т. 6, № 2. - C. 49-53.

17. Чорна I. В. Клінічна ензимологія. Ензимодіагностика : навчальний посібник / І. В. Чорна, I. Ю. Висоцький. - Суми, 2013. - 243 с.

18. Клінічна біохімія : підручник / [Бойків Д. П., Бондарчук Т. І., Іванків О. Л. та ін.] ; за ред. О. Я. Склярова. - К. : Медицина, 2006. - 432 с.

19. Росльй И. М. Правила чтения биохимического анализа : руководство для врача / И. М. Рослый, М. Г. Водолажская. - М. : Медицинское информационное агентство, 2010. - 96 с.

20. Энциклопедия клинических лабораторных тестов / [пер. с англ. под ред. В. Меньшикова]. М. : Лабинформ, 1997. - 960 с. 
21. Биохимия : учебник / [под ред. Е. С. Северина]. - [2-е изд., испр.]. - М. : ГЭОТАР-Медиа, 2004. $-784 \mathrm{c}$.

22. AUDIT: the alcohol use disorders identification test. Guidelines for use in primary care / [Babor T. F., Higgins-Biddle J. C., Saunders J. B., Monteiro M. G. ]. - Geneva : WHO, 2001. - 28 p.

23. Інформаційний лист МОЗ України № 249-2018. Спосіб діагностики клінічної специфіки і прогнозу перебігу алкогольної залежності у осіб з різним психотравматичним досвідом і рівнем психосоціального стресу / Сосін І. К., Гапонов К. Д., Гончарова О. Ю., Маркова М. В. - К., 2018. - 4 с.

24. Гапонов К. Д. Порівняльний аналіз вираженості проявів алкогольної залежності у осіб з різним психотравматичним досвідом та рівнем психосоціального стресу / К. Д. Гапонов // Український вісник психоневрології. - 2018. - Т. 26, вип. 3 (96). - С. 14-17.

25. Гайдабрус A. B. Розлади внаслідок уживання алкоголю у колишніх військовослужбовців «у дзеркалі» тесту AUDIT / А. В. Гайдабрус // Український вісник психоневрології. - 2014. - Т. 22 , вип. 1 (78). - С. 114-120.

26. Serum glutamic-oxaloacetic transaminase (GOT) and glutamic-pyruvic transaminase (GPT) levels in children and adolescents with intellectual disabilities / J. D. Lin, P. Y. Lin, L. M. Chen [et al.] // Res. Dev. Disabil. - 2010. - Vol. 31 (1). - P. 172-177.

27. Маклеллан T. Индекс тяжести зависимости: версия Treatnet: Руководство и опросник / [Маклеллан Т., Каризе Д.] ; сост. С. В. Пхиденко, А. В. Карпец, А. С. Циулина. - М. : Верди, 2009. - 128 с.

\section{References}

1. Hetman L., Hrytsenko T., Ivanchuk I., Kolomiiets V., Skrynnyk-Naduta K., Filippovych S., Shost A. (2017). Intehrovana dopomoha dlia osib iz psykhichnymy ta povedinkovymy rozladamy vnaslidok vzhyvannia opioidiv - patsiientiv zamisnoi pidtrymuvalnoi terapii: praktychnyi posibnyk [Integrated care for people with mental and behavioral disorders as a result of opioid use - substitution maintenance therapy patients: a practical guide]. Kiev: MBF «Alians hromadskoho zdorovia», TOV «Ahentstvo «Ukraina», 128 p. [in Ukrainian].

2. Dvoriak S.V., Karahodina O.H., Morozova O.S., Pykalo I.I., Dumchev K.V. (2016). Intehrovane likuvannia khvorykh na opioidnu zalezhnist v umovakh tsentriv pervynnoi medyko-sanitarnoi dopomohy: navchalno-metodychnyi posibnyk [Integrated treatment of opioid addiction patients in primary health care centers: a toolkit]. Kiev: Drukarskyi dvir Oleha Fedorova, 76 p. [in Ukrainian].

3. Sosin I.K., Chuiev Yu.F. (Eds.). (2014). Narkolohiia: natsionalnyi pidruchnyk [Narcology: National Textbook]. Kharkiv: Kolehium, 1500 p. [in Ukrainian].

4. Sosin I.K., Skvira I.M., Mitsura V.M., Chuiev Yu.F., Honcharova O.Yu. (2016). Rannia diahnostyka alkoholnoi zalezhnosti v praktytsi simeinoho likaria [Early diagnosis of alcohol dependence in the practice of a family doctor]. Zdobutky klinichnoi i eksperymentalnoi medytsyny-Achievements of Clinical and Experimental Medicine, № 1, pp. 69-72 [in Ukrainian].

5. Sosin I.K., Skvira I.M., Chuiev Yu.F., Honcharova O.Iu. (2014). Intehrovana diahnostychna identyfikatsiia alkoholnoi zalezhnosti u zahalnosomatychnii praktytsi [Integrated diagnostic identification of alcohol dependence in somatic practice]. Skhidnoievropeiskyi zhurnal vnutrishnoi i simeinoi medytsynyEastern European Journal of Internal and Family Medicine, № 1, pp. 95-99 [in Ukrainian].

6. GBD 2016 Alcohol Collaborators. (2016). Alcohol use and burden for 195 countries and territories, 1990-2016: a systematic analysis for the Global Burden of Disease Study 2016. Lancet Psychiatry, vol. 392, issue 10152, pp. 1015-1035, pii: S2215-0366(18)30337-7, DOI 10.1016/S0140-6736(18)31310-2.

7. Markova M.V., Markov A.R., Agisheva N.K., Martinenko S.A. (2017). Information and psychological war as a macrosocial stress-development factor of maladaptive states in civilian population: a pathogenetic model and bases of psychocorrection. Psychiatry, Psychotherapy and Clinical Psychology, № 4, pp. $534-546$.

8. Maruta N.O., Markova M.V. (2015). Informatsiino-psykholohichna viina yak novyi vyklyk suchasnosti: stan problemy ta napriamky yii podolannia [Informational and psychological war as a new challenge to the presence: the state of the problem and directions for overcoming it]. Ukrainskyi visnyk psykhonevrolohii - Ukrainian Journal of Psychoneurology, vol. 23, issue 3 (84), pp. 21-28 [in Ukrainian].

9. Markova M.V., Kozyra P.V. (2015). Poststresovi dezadaptyvni stany na tli sotsialnykh zmin: analiz problemy [Post-stress maladaptation during of social changes: An analysis of the problem]. Medychna psykholohiia - Medical Psychology, № 1 (37), pp. 8-13 [in Ukrainian]. 
10. Becker H.C. (2012). Effects of alcohol dependence and withdrawal on stress responsiveness and alcohol consumption. Alcohol Research, vol. 34 (4), pp. 448-458.

11. Moonat S., Pandey S.C. (2012). Stress, epigenetics, and alcoholism. Alcohol Res., vol. 34 (4), pp. 495-505.

12. Mackey T.K., Strathdee S.A. (2015). Responding to the public health consequences of the Ukraine crisis: an opportunity for global health diplomacy. J. Int. AIDS Soc., vol. 18, pp. 19410.

13. Cadet J.L. (2016). Epigenetics of stress, addiction, and resilience: therapeutic implications. Molecular Neurobiology, vol. 53 (1), pp. 545-560.

14. Palmisano M., Pandey S.C. (2017). Epigenetic mechanisms of alcoholism and stress-related disorders. Alcohol, vol. 60, pp. 7-18.

15. Linskyi I.V., Haidabrus A.V. (2013). Osoblyvosti somatychnoho statusu kolyshnikh viiskovosluzhbovtsiv, zalezhnykh vid alkoholiu [Features of somatic status of former alcohol addicts]. Svit medytsyny ta biolohii - The World of Medicine and Biology, № 4 (42), pp. 16-21 [in Ukrainian].

16. Makarenko T.M., Radchenko O.M. (2017). Spivvidnoshennia biokhimichnykh pokaznykiv krovi v medychnii praktytsi: kliniko-diahnostychne znachennia [Correlation of biochemical parameters of blood in medical practice: clinical and diagnostic value]. Praktykuiuchyi likar-Practitioner, vol. 6, № 2, pp. 49-53 [in Ukrainian].

17. Chorna I.V., Vysotskyi I.Yu. (2013). Klinichna enzymolohiia. Enzymodiahnostyka: navchalnyi posibnyk [Clinical enzymology. Enzymodiagnostics: a textbook]. Sumy, 243 p. [in Ukrainian].

18. Boikiv D.P., Bondarchuk T.I., Ivankiv O.L. et al. (2006). Klinichna biokhimiia: pidruchnyk [Clinical biochemistry: a textbook]. O.Ia. Skliarova (Ed.). Kiev: Medytsyna, 432 p. [in Ukrainian].

19. Roslyi I.M., Vodolazhskaia M.H. (2010). Pravila chteniia biokhimicheskoho analiza: Rukovodstvo dlia vracha [Rules for reading biochemical analysis: a Guide for a physician]. Moscow: Meditsinskoie informatsionnoie ahentstvo, $96 \mathrm{p}$. [in Russian].

20. Menshikova V. (Eds.). (1997). Entsiklopediia klinicheskikh laboratornykh testov [Encyclopedia of Clinical Laboratory Tests]. (transl. from English). Moscow: Labinform, 960 p. [in Russian].

21. Severin E.S. (Eds.). (2004). Biokhimiia: Uchebnik [Biochemistry: Textbook]. (2 ${ }^{\text {nd }}$ ed.). Moscow: HEOTAR-Media, 784 p. [in Russian].

22. Babor T.F., Higgins-Biddle J.C., Saunders J.B., Monteiro M.G. (2001). AUDIT: the alcohol use disorders identification test. Guidelines for use in primary care. Geneva: WHO, 28 p.

23. Sosin I.K., Haponov K.D., Honcharova O.Iu., Markova M.V. (2018). Informatsiinyi lyst MOZ Ukrainy № 249-2018. Sposib diahnostyky klinichnoi spetsyfiky i prohnozu perebihu alkoholnoi zalezhnosti u osib z riznym psykhotravmatychnym dosvidom i rivnem psykhosotsialnoho stresu [Ministry of Health of Ukraine information sheet № 249-2018. Method of the diagnosis of clinical specificity and prognosis of alcohol dependence in persons with different psychotraumatic experience and level of psychosocial stress]. Kyiv, 4 p. [in Ukrainian].

24. Haponov K.D. (2018). Porivnialnyi analiz vyrazhenosti proiaviv alkoholnoi zalezhnosti u osib z riznym psykhotravmatychnym dosvidom ta rivnem psykhosotsialnoho stresu [Comparative analysis of the severity of alcohol dependence among patients with different psychotraumatic experiences and levels of psychosocial stress]. Ukrainskyi visnyk psykhonevrolohii - Ukrainian Journal of Psychoneurology, vol. 26, issue 3 (96), pp. 14-17 [in Ukrainian].

25. Haidabrus A.V. (2014). Rozlady vnaslidok uzhyvannia alkoholiu u kolyshnikh viiskovosluzhbovtsiv «u dzerkali» testu AUDIT [Disorders due to alcohol consumption among the former soldiers in the mirror of AUDIT test]. Ukrainskyi visnyk psykhonevrolohii - Ukrainian Journal of Psychoneurology, vol. 22, issue 1 (78), pp. 114-120 [in Ukrainian].

26. Lin J.D., Lin P.Y., Chen L.M., Fang W.H., Lin L.P., Loh C.H. (2010). Serum glutamic-oxaloacetic transaminase (GOT) and glutamic-pyruvic transaminase (GPT) levels in children and adolescents with intellectual disabilities. Res. Dev. Disabil., vol. 31 (1), pp. 172-177.

27. Maklellan T., Karize D. (2009). Indeks tiazhesti zavisimosti: versiia Treatnet: Rukovodstvo $i$ oprosnik [Addiction severity index: Treatnet Version: Manual and Questionnaire]. S.V. Pkhydenko, A.V. Karpets, A.S. Tsyulyna (Compilers). Moscow: Verdi, 128 p. [in Russian]. 


\section{И.К. Сосин, К.Д. Гапонов, А.Ю. Гончарова ПРОГНОЗИРОВАНИЕ ТЯЖЕСТИ РАССТРОЙСТВА В РЕЗУЛЬТАТЕ УПОТРЕБЛЕНИЯ АЛКОГОЛЯ У БОЛЬНЫХ В ЗАВИСИМОСТИ ОТ УРОВНЯ ПСИХОСОЦИАЛЬНОГО СТРЕССА И СОСТОЯНИЯ ГЕПАТОБИЛИАРНОЙ СИСТЕМЫ В СВЕТЕ КОНЦЕПЦИИ ИНТЕГРИРОВАННОЙ ДИАГНОСТИКИ И ТЕРАПИИ НАРКОПАТОЛОГИИ}

Разрабатывали способ определения и прогнозирования тяжести расстройств, возникающих вследствие употребления алкоголя, у больных в зависимости от уровня психосоциального стресса и состояния пищеварительной системы в свете концепции интегрированной диагностики и терапии наркопатологии для использования его врачами первичного звена медико-санитарной помощи. При разработке модели выделены три основные группы факторов, которые, по данным исследования, повлияли на формирование тяжести расстройств вследствие употребления алкоголя: выраженность аддиктивной симптоматики (по AUDIT), уровень испытываемой пациентами стрессовой нагрузки (по тесту Л. Ридера) и состояние пищеварительной системы (по коэффициенту де Ритиса). Создана модель, которая математически описывает соотношение различных факторов в формировании тяжести расстройств, развивающихся вследствие употребления алкоголя, и дает возможность количественно оценить вероятностное состояние у конкретного больного расстройствами вследствие употребления алкоголя. Показано, что предложенная модель характеризуется высокой детерминантностью и пригодна для применения в практике здравоохранения для прогнозирования тяжести расстройств вследствие употребления алкоголя у больных алкогольной зависимостью.

Ключевые слова: алкогольная зависимость, тяжесть расстройств вследствие употребления алкоголя, психосочиальный стресс, коэффиџиент де Ритиса, нелинейная многомерная модель, моделирование и прогнозирование.

\section{I.K. Sosin, K.D. Gaponov, O.Yu. Goncharova PROGNOSTICATION OF THE DIFFICULTIES OF DISORDERS DUE TO ALCOHOL CONSUMPTION IN PATIENTS, ACCORDING TO THEIR PSYCHOSOCIAL STRESS LEVELAND THE STATE OF THE HEPATOBILIARY SYSTEM IN THE LIGHT OF THE CONCEPT OF INTEGRATED DIAGNOSIC AND NARCOPATHOLOGY THERAPY}

A method was developed for determining and predicting the severity of disorders resulting from alcohol use in patients depending on the level of psychosocial stress and the state of the digestive system in the light of the concept of integrated diagnosis and treatment of drug pathology for use by primary care physicians. When developing the model, three main groups of factors were identified that, according to the study, influenced the formation of the severity of disorders due to alcohol consumption: the severity of addictive symptoms (by the AUDIT), the level of stress load experienced by patients (by L. Rider's test) and the state of the digestive system (by the De Ritis Ratio). A model has been created that mathematically describes the ratio of various factors in the formation of the severity of disorders developing as a result of drinking alcohol, and makes it possible to quantify the probabilistic state of a particular patient with disorders due to drinking. It is shown that the proposed model is characterized by high determinism and is suitable for use in healthcare practice to predict the severity of disorders due to alcohol use in patients with alcohol dependence.

Keywords: alcohol dependence, severity of disorders due to alcohol consumption, psychosocial stress, the De Ritis Ratio, nonlinear multidimensional model, modeling and prognostication.

Надійшла 13.02.19

\section{Відомості про автора}

Сосін Іван Кузьмич - доктор медичних наук, професор, завідувач кафедри наркології, Заслужений винахідник України, академік Української академії наук.

Адреса: 61176, м. Харків, вул. Амосова, 58, Харківська медична академія післядипломної освіти.

Тел.: +38(057)723-00-37.

E-mail: isosin@ukr.net.

ORCID: https://orcid.org/0000-0002-4858-9585. 
Гапонов Костянтин Дмитрович - кандидат медичних наук, головний лікар КНП ХОР «Обласний наркологічний диспансер», доцент кафедри наркології Харківської медичної академії післядипломної освіти МОЗ України.

Адреса: 61045, м. Харків, вул. Очаківська, 15, КНП ХОР «Обласний наркологічний диспансер»;

61176 , м. Харків, вул. Амосова, 58, Харківська медична академія післядипломної освіти.

Тел.: +38(050)669-29-66.

E-mail: kostiantyn1807@gmail.com.

ORCID: https://orcid.org/0000-0002-2835-1027.

Гончарова Олена Юрї̈вна - кандидат медичних наук, доцент кафедри наркології Харківської медичної академії післядипломної освіти.

Адреса: 61036, м. Харків, вул. Чорноморська, 5, Харківська медична академія післядипломної освіти.

Тел.: +38(057)723-00-37, +38(057)723-01-24.

E-mail: ollenagoncharova@ukr.net.

ORCID: https://orcid.org/0000-0003-1842-9406. 